EXPERIMENTAL STUDY

\title{
Mechanisms for altered reproductive function in female rats following neonatal administration of raloxifene
}

\author{
M Tena-Sempere, M L Barreiro, E Aguilar and L Pinilla \\ Department of Cell Biology, Physiology and Immunology, Physiology Section, Faculty of Medicine, University of Córdoba, Avda Menendez Pidal, \\ 14004 Córdoba, Spain \\ (Correspondence should be addressed to L Pinilla; Email: filagbee@uco.es)
}

\begin{abstract}
Objective: Raloxifene is a non-steroidal selective estrogen receptor modulator (SERM) that mimics estrogenic activity on bone density and blood lipid concentration without uterotropic actions. Previous data from our laboratory indicated that, as is the case for estrogen, neonatal administration of raloxifene disturbed normal differentiation of the hypothalamic circuitries governing the gonadotropic axis. In contrast, raloxifene did not act in the same way as estrogen does on the neuronal systems controlling sexual receptivity in the female rat. At present, however, the mechanisms for these organizing effects of raloxifene are not completely elucidated.

Design and methods: To analyze this phenomenon, female rats were injected daily with raloxifene $(50,100,250$ or $500 \mu \mathrm{g} /$ rat per day) between days 1 and 5 of age. On day 23, hypothalamic gonadotropin-releasing hormone (LHRH) mRNA expression was assessed, and pituitary and plasma luteinizing hormone (LH) and follicle-stimulating hormone (FSH) levels were measured in basal and LHRH-stimulated conditions. In addition, LH and FSH responses to ovariectomy were evaluated in raloxifene-treated females. Finally, we monitored the ability of neonatal administration of a potent LHRH agonist ([D-Ala $\left.{ }^{6}, \mathrm{D}-\mathrm{Gly}^{10}\right]$-LHRH ethylamide; $0.01 \mu \mathrm{g} / \mathrm{kg}$ per $12 \mathrm{~h}$ on days $\left.1-5\right)$ to counteract the effects of raloxifene.

Results: Our analyses demonstrated that prepubertal rats (23-day-old females) treated neonatally with raloxifene showed decreased hypothalamic LHRH mRNA expression levels, reduced pituitary content of LH and FSH, reduced basal and LHRH-stimulated LH secretion in vivo and in vitro, and decreased response to ovariectomy. In addition, adult females treated neonatally with raloxifene showed anovulation and reduced serum LH levels; these effects were not prevented by the simultaneous administration of a LHRH agonist.

Conclusion: In conclusion, our data demonstrate that neonatal administration of raloxifene can disrupt the programming of hypothalamic-pituitary-ovarian axis function. Reduced LH secretion, under basal and LHRH-stimulated conditions and after ovariectomy, is probably related to decreased LHRH expression, reduced pituitary LH content and/or decreased pituitary responsiveness to hypothalamic LHRH.
\end{abstract}

European Journal of Endocrinology 150 397-403

\section{Introduction}

In rodents, organization of the neural circuitries involved in the control of neuroendocrine function, and especially of those serving reproductive activity, occurs during the perinatal period $(1-4)$. Such a process of differentiation is critically dependent on the sex steroid input upon the hypothalamic centers (5-9).

Raloxifene, a non-steroidal selective estrogen receptor modulator (SERM), was recently developed for improving the management of highly prevalent diseases in menopausal women. Thus, a body of experimental data indicates that raloxifene is devoid of uterotropic activity and blocks the effects of estrogen in the breast, but that it mimics estrogenic activity in relation to bone density and blood lipid concentration (10-13). At present, however, the estrogenic/antiestrogenic activity of raloxifene in the organization and regulation of the neural network controlling reproductive function remains to be fully elucidated. In fact, conflicting results on the presence or absence of any estrogenic activity of raloxifene on hypothalamicpituitary function have been presented (14-16). In this context, data from our laboratory indicated that administration of raloxifene during the neonatal period of hypothalamic sex differentiation induced an estrogen-like effect on the functional organization of the hypothalamic-pituitary unit $(17,18)$; however, 
raloxifene did not act in the same way as estrogen on the neuronal systems controlling sexual receptivity in the female rat (18). In adult animals, raloxifene increased serum prolactin concentrations and decreased luteinizing hormone (LH) levels in ovariectomized rats, thus indicating an activational estrogenic action of this SERM in the regulation of hypothalamic-pituitary function (19).

On the above basis, the present work was undertaken in order to evaluate the mechanisms involved in the effects of raloxifene on the functional organization of the hypothalamic-pituitary unit. To this end, female rats were treated with different daily doses of raloxifene between days 1 and 5 of age, and several aspects of the function of the gonadotropin-releasing hormone (LHRH)-LH axis were analyzed in the prepubertal (23 days old) period. In addition, we examined the contribution of decreased LHRH secretion (during the neonatal period of raloxifene administration) to the plethora of reproductive effects of raloxifene.

\section{Material and methods}

\section{Animals and drugs}

Wistar rats born in our laboratory were kept under controlled conditions of light (12 h light: $12 \mathrm{~h}$ darkness; lights on at $0700 \mathrm{~h})$ and temperature $\left(22^{\circ} \mathrm{C}\right)$, with free access to pelleted food (Pacsa Sanders, Seville, Spain) and tap water. On day 1 of post-natal life each dam was left with eight pups. Raloxifene chlorydrate (Evista), a SERM, was purchased from Eli Lilly. The luteinizing hormone releasing hormone (LHRH) and the LHRH agonist (LHRH-A; [D-Ala ${ }^{6}$, D-Gly $\left.{ }^{10}\right]-\mathrm{LHRH}$ ethylamide) were obtained from Sigma. All drugs were dissolved in $0.9 \% \mathrm{NaCl}(\mathrm{w} / \mathrm{v})$. All experimental procedures were approved by the Ethical Committee for Animal Experimentation of the University of Cordoba and were conducted in accordance with EU guidelines for animal care and experimentation.

\section{Experimental designs}

Experiment 1 was carried out to analyze the effects of neonatal administration of raloxifene on the function of the hypothalamic-pituitary-ovarian axis in prepubertal rats. To this end, female rats, injected daily i.p. between days 1 and 5 of age with different doses of raloxifene $(50,100,250$ or $500 \mu \mathrm{g} / \mathrm{rat}$ per day) or vehicle, were decapitated at 23 days old. At this point, ovarian weight was recorded, and hypothalamus, pituitary and serum samples were collected from the different experimental groups; samples were used to monitor GnRH mRNA expression levels at the hypothalamus and LH and FSH content and levels at the pituitary and in serum respectively.

In addition, in Experiment 2, the contribution of altered responses to LHRH to the effects of raloxifene observed in vivo was studied. Thus, pituitary responsiveness to LHRH was assessed using in vivo and in vitro settings. For in vitro experiments, female rats, injected i.p. between days 1 and 5 of age with raloxifene ( $500 \mu \mathrm{g} /$ day) or vehicle, were decapitated on day 23 of age; anterior pituitaries were removed and placed in scintillation vials in a Dubnoff shaker at $38^{\circ} \mathrm{C}$ with constant shaking ( 60 cycles/min) under an atmosphere of $95 \% \quad \mathrm{CO}_{2}-5 \% \quad \mathrm{O}_{2}$. Each vial contained $1 \mathrm{ml}$ Dulbecco's modified Eagle's medium (DMEM). After $1 \mathrm{~h}$ of pre-incubation the medium was replaced by fresh medium, with or without LHRH $\left(10^{-6} \mathrm{M}\right)$, and samples were collected $120 \mathrm{~min}$ after incubation for hormone determinations (see below). For in vivo experiments, female rats, injected i.p. between days 1 and 5 of age with raloxifene $(50,100,250$ or $500 \mu \mathrm{g} /$ day $)$ or vehicle, were injected on day 23 with LHRH $(1 \mu \mathrm{g})$ or vehicle. Blood samples were obtained by jugular venipuncture under light ether anesthesia before, and 45 min after, injection of LHRH.

The above experiments indicated that the neonatal exposure to raloxifene induces multiple changes at different levels of the LHRH-LH system. To expand these findings, Experiment 3 investigated LH response to ovariectomy in female rats treated neonatally with raloxifene. To this end, female rats injected i.p. between days 1 and 5 of age with raloxifene $(50,100,250$ or $500 \mu \mathrm{g} /$ day) or vehicle were ovariectomized on day 23 of age under light ether anesthesia. Blood samples were obtained by jugular venipuncture at $1000 \mathrm{~h}$ before ovariectomy and 1,7 and 14 days after ovariectomy.

Finally, in Experiment 4 we assessed the contribution of decreased LHRH input during neonatal raloxifene treatment to the plethora of reproductive changes observed in the female. Female rats were injected between days 1 and 5 of age with vehicle, raloxifene (250 or $500 \mu \mathrm{g} /$ day), LHRH-A $(0.01 \mu \mathrm{g} / \mathrm{kg}$ per $12 \mathrm{~h})$, or raloxifene $(250$ or $500 \mu \mathrm{g} /$ day $)$ plus LHRH-A $(0.01 \mu \mathrm{g} / \mathrm{kg}$ per $12 \mathrm{~h})$. At adult age, vaginal smears were monitored daily for assessment of ovarian cyclicity; the appearance of epithelial cornified cells on 12 or more consecutive days was considered as constant vaginal estrus (CVE). Animals from the experimental groups were killed by decapitation around day 90 and trunk blood was collected. Cycling animals were sampled in the diestrous 1 phase.

\section{Hormone assays}

Trunk blood was collected and serum separated by centrifugation and stored at $-20{ }^{\circ} \mathrm{C}$ until analyzed. Pituitaries were dissected, weighed and homogenized in $1 \mathrm{ml}$ physiological saline containing urea $(2.5 \mathrm{~mol} / \mathrm{l})$ and subjected to ultrasonic treatment (20). Samples were centrifuged for $20 \mathrm{~min}$ at $2800 \boldsymbol{g}$ and the supernatant was frozen at $-20^{\circ} \mathrm{C}$ until analysis for hormone content. $\mathrm{LH}$ and follicle-stimulating hormone (FSH) 
concentrations were measured by specific RIAs using kits supplied by the National Hormone and Pituitary Program (NIDDK, Bethesda, MD, USA) and hormone concentrations were expressed using LH-RP-3 and FSH-RP-2 as standards. All samples were measured in duplicate and all samples from each experiment were measured in the same assay. Intra-assay coefficients of variations were below $11 \%$, the sensitivities of the assay were 20 and $7.5 \mathrm{pg} /$ tube for LH and FSH respectively.

\section{Analysis of GnRH mRNA levels by semi-quantitative RT-PCR}

Total RNA was isolated from hypothalamic samples of the experimental groups using the single-step, acid guanidinium thiocyanate-phenol-chloroform extraction method (21). Hypothalamic expression of $\mathrm{GnRH}$ mRNA was assessed by RT-PCR, optimized for semiquantitative detection, using a specific primer pair (forward, 5'-GCA CTA TGG TCA CCA GCG GG -3'; reverse, 5'-CAT GGA TCT CAG CGT CAA TG-3') flanking a 477 bp fragment of the coding area of GnRH cDNA, as described in detail elsewhere (22). As internal control, amplification of a $290 \mathrm{bp}$ fragment of L19 ribosomal protein mRNA was carried out in parallel in each sample, using the primer pair L19 sense (5'-GAA ATC GCC AAT GCC AAC TC-3') and L19 antisense (5'-ACC TTC AGG TAC AGG CTG TG-3'), as described elsewhere (23).

For amplification of the targets, RT and PCR were run in two separate steps. In addition, to enable appropriate amplification in the exponential phase for each target, PCR amplification of specific signal and L19 ribosomal protein transcripts was carried out in separate reactions; the reactions used different numbers of cycles but similar amounts of the corresponding cDNA templates, generated in single RT reactions, as previously described (23). PCR reactions consisted of a first denaturing cycle at $97^{\circ} \mathrm{C}$ for $5 \mathrm{~min}$, followed by a variable number of cycles of amplification defined by denaturation at $96^{\circ} \mathrm{C}$ for $1.5 \mathrm{~min}$, annealing at $57^{\circ} \mathrm{C}$ for $1.5 \mathrm{~min}$ and extension at $72^{\circ} \mathrm{C}$ for $3 \mathrm{~min}$. Different numbers of cycles were tested to optimize amplification in the exponential phase of PCR (data not shown). On this basis, 32 and 23 PCR cycles were chosen for further analysis of GnRH and L19 species respectively; these conditions allowed amplification in the linear range and, thus, semi-quantitative comparison between control and raloxifene-treated samples.

PCR-generated DNA fragments were resolved in Tris-borate-buffered $1.5 \%$ agarose gels, and visualized by ethidium bromide staining. Specificity of PCR products was confirmed by direct sequencing (NewBiotechnic Ltd, Sevilla, Spain). In all assays, liquid controls and reactions without RT were included that yielded negative amplification (data not shown), thus ruling out the possibility of spurious amplification of the signals. Quantitative evaluation of RT-PCR signals was carried out by densitometric scanning using an image analysis system (1-D Manager, TDI Ltd, Madrid, Spain). The values for the specific targets were normalized to those of internal controls to express arbitrary units of relative abundance of the transcripts.

\section{Statistics}

Data are expressed as means \pm S.E.M., 10-12 animals per group. Semi-quantitative data from RT-PCR analyses are presented as means \pm S.E.M. of at least four independent observations. Differences between groups were determined by one- or two-way ANOVA followed by Tukey's test. $\chi^{2}$ evaluation was used selectively for comparing data for the percentage of anovulatory cycles.

\section{Results}

Neonatal administration of raloxifene, at all doses tested, induced in prepubertal (23 days old) female rats a significant $(P \leq 0.01)$ reduction in ovarian weight and serum LH and FSH concentrations (Table 1). The highest doses of raloxifene (100, 250 and $500 \mu \mathrm{g} /$ day between days 1 and 5 of age) also induced a significant $(P \leq 0.01)$ decrease in pituitary LH and FSH content (Table 1). In addition, raloxifene, at the highest dose tested $(500 \mu \mathrm{g} /$ day $)$, significantly reduced $(P \leq 0.01) \mathrm{LHRH}$ mRNA expression levels at the hypothalamus (Fig. 1).

In vitro, basal $\mathrm{LH}$ and $\mathrm{FSH}$ release was significantly lower $(P \leq 0.01)$ in pituitaries from female rats neonatally treated with $500 \mu \mathrm{g} /$ day of raloxifene (Table 2). In addition, in raloxifene-treated rats, $\mathrm{LH}$ response to LHRH was significantly reduced $(P \leq 0.01)$ while the FSH response remained unaltered. In keeping with

Table 1 Ovarian weight, serum concentrations of $\mathrm{LH}$ and $\mathrm{FSH}$, and pituitary $\mathrm{LH}$ and $\mathrm{FSH}$ content in 23-day-old female rats treated with raloxifene or vehicle between 1 and 5 days of age.

\begin{tabular}{|c|c|c|c|c|c|}
\hline Treatment & $\begin{array}{l}\text { Ovarian weight } \\
\text { (mg \% g BW) }\end{array}$ & $\begin{array}{c}\text { LH } \\
\text { (ng/ml) }\end{array}$ & $\begin{array}{c}\text { FSH } \\
(\mathrm{ng} / \mathrm{ml})\end{array}$ & $\begin{array}{c}\text { LH } \\
(\mu \mathrm{g} / \text { pituitary })\end{array}$ & $\begin{array}{c}\text { FSH } \\
(\mu \mathrm{g} / \text { pituitary })\end{array}$ \\
\hline Vehicle & $31.4 \pm 1.3$ & $0.3 \pm 0.02$ & $12.6 \pm 1.3$ & $4.3 \pm 0.5$ & $0.20 \pm 0.01$ \\
\hline Raloxifene (50 $\mu \mathrm{g} /$ day) & $19.0 \pm 2.3^{* *}$ & $0.1 \pm 0.02^{* *}$ & $4.9 \pm 0.9 * *$ & $3.1 \pm 0.4^{*}$ & $0.16 \pm 0.008$ \\
\hline Raloxifene (100 $\mu \mathrm{g} /$ day $)$ & $18.0 \pm 1.2^{\star \star}$ & $0.07 \pm 0.01^{* *}$ & $3.9 \pm 0.6^{\star *}$ & $1.4 \pm 0.2^{\star *}$ & $0.11 \pm 0.01^{\star \star}$ \\
\hline Raloxifene (250 $\mu \mathrm{g} /$ day $)$ & $19.7 \pm 1.8^{\star \star}$ & $0.1 \pm 0.02^{\star \star}$ & $4.3 \pm 0.6^{\star *}$ & $0.9 \pm 0.09 * *$ & $0.09 \pm 0.06^{\star \star}$ \\
\hline Raloxifene (500 $\mu \mathrm{g} /$ day $)$ & $19.6 \pm 1.1^{* \star}$ & $0.1 \pm 0.01 * *$ & $3.9 \pm 0.4^{\star \star}$ & $1.2 \pm 0.1^{\star \star}$ & $0.09 \pm 0.006^{* *}$ \\
\hline
\end{tabular}

Data are expressed as means \pm S.E.M.; 10-12 animals per group.

${ }^{\star} P<0.05 ;{ }^{\star \star} P<0.01$ vs vehicle-injected group (ANOVA followed by Tukey's test); ND, not determined. 

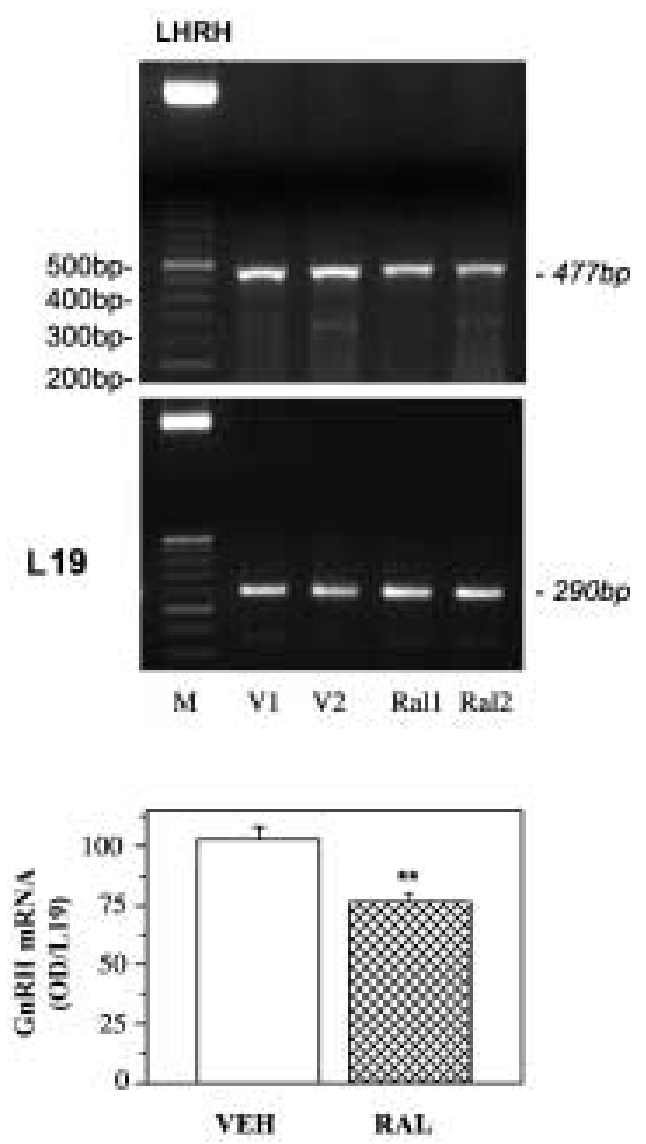

Figure 1 Hypothalamic expression of LHRH mRNA in 23-day-old female rats injected neonatally with raloxifene $(500 \mu \mathrm{g} /$ rat per day) or vehicle. Upper panel, representative ethidium bromide stained gel electrophoresis of GnRH mRNA levels in hypothalamic samples from control (V) and raloxifene-treated (Ral) animals. A $50 \mathrm{bp}$ molecular weight marker was used. (M) Parallel amplification of ribosomal protein L19 transcript was conducted in each sample and served as an internal control for reaction efficiency and RNA loading. Lower panel, compilation of semi-quantitative data of LHRH mRNA steady-state levels in control (VEH) and raloxifene-treated (RAL) groups. Data are expressed as means \pm S.E.M. (four independent determinations per group). ${ }^{*} P \leq 0.01$ vs control samples (ANOVA followed by Tukey's test).

our in vitro data, LH responses to LHRH were also significantly $(P \leq 0.05)$ reduced in vivo in females neonatally injected with 250 or $500 \mu \mathrm{g} /$ day raloxifene (Table 3); however, the reduction in $\mathrm{LH}$ responses to
LHRH was not statistically significant in groups injected with lower doses of raloxifene (50 and $100 \mu \mathrm{g} /$ day). In vivo, LHRH-induced FSH responses were similar in control and in all raloxifene-treated groups.

In addition to hypothalamic LHRH mRNA levels, and basal and LHRH-stimulated gonadotropin levels, LH and FSH responses to ovariectomy were assessed in prepubertal females treated neonatally with raloxifene. Serum concentrations of LH were reduced in all raloxifene-treated female rats 1,7 and 14 days after ovariectomy (Fig. 2A). A similar trend was observed for FSH responses to ovariectomy, although these appeared to be dependent on both the doses of raloxifene tested and the time elapsed after ovariectomy. Thus, serum FSH levels were significantly lower $(P \leq 0.01)$ in all groups of raloxifene-treated females 1 and 7 days after ovariectomy, but only the highest dose of raloxifene $(500 \mu \mathrm{g} /$ day $)$ induced a significant reduction $(P \leq 0.01)$ in serum FSH levels on day 14 postovariectomy (Fig. 2B).

Finally, an evaluation was carried out of the ability of neonatal treatment with a potent LHRH-A to counteract the reproductive effects of high doses of raloxifene, administered neonatally. In line with previous results from our group (17), adult female animals treated neonatally with 250 or $500 \mu \mathrm{g} /$ day of raloxifene showed anovulation with the persistent presence of cornified cells in vaginal smears (Table 4 ), as well as a decrease $(P \leq 0.01)$ in serum LH levels (Table 5). Simultaneous administration of LHRH-A and raloxifene during the neonatal period did not modify the reproductive effects of raloxifene given alone (Tables 4 and 5). Per se, the doses of LHRH-A tested neonatally did not cause any significant alteration in female reproductive function in the adult age (Tables 4 and 5, and data not shown).

\section{Discussion}

SERMs are synthetic compounds with predominant estrogenic or anti-estrogenic activities depending on the tissue and/or the biological action. Previous studies from our laboratory have shown that male and female rats treated with raloxifene during the critical neonatal period of hypothalamic sex differentiation exhibited a plethora of reproductive alterations similar to those observed after neonatal administration of estradiol

Table $2 \mathrm{LH}$ and FSH secretion by pituitaries from 23-day-old female rats, treated with raloxifene ( $500 \mu \mathrm{g} / \mathrm{day})$ or vehicle between and days 1 and 5 of age, after 120 min incubation with medium containing LHRH or medium alone.

\begin{tabular}{|c|c|c|c|c|}
\hline \multirow[b]{2}{*}{ Treatment } & \multicolumn{2}{|c|}{ LH (ng/pituitary) } & \multicolumn{2}{|c|}{ FSH (ng/pituitary) } \\
\hline & Vehicle & Raloxifene & Vehicle & Raloxifene \\
\hline $\begin{array}{l}\text { DMEM } \\
\text { LHRH }\left(10^{-6} \mathrm{M}\right)\end{array}$ & $\begin{array}{l}0.19 \pm 0.09 \\
2.24 \pm 0.51^{\star *}\end{array}$ & $\begin{array}{l}0.03 \pm 0.01 \dagger \\
0.30 \pm 0.07^{* *} \dagger\end{array}$ & $\begin{array}{l}112.73 \pm 17.25 \\
241.15 \pm 20.93^{\star *}\end{array}$ & $\begin{array}{c}18.31 \pm 4.17 \dagger \\
179.19 \pm 32.33^{* *}\end{array}$ \\
\hline
\end{tabular}

Data are expressed as means \pm S.E.M.; $10-12$ pituitaries per group.

$\star \star P<0.01$ DMEM vs LHRH; $† P<0.01$ vehicle vs raloxifene-injected group (ANOVA followed by Tukey's test). 
Table 3 Serum LH and FSH concentrations in 23-day-old female rats treated with raloxifene or vehicle on between days 1 and 5 of age, before and $45 \mathrm{~min}$ after LHRH ( $1 \mu \mathrm{g} / \mathrm{rat})$ administration in vivo.

\begin{tabular}{lcccc}
\hline & \multicolumn{2}{c}{ LH $(\mathrm{ng} / \mathrm{ml})$} & \multicolumn{2}{c}{ FSH $(\mathrm{ng} / \mathrm{ml})$} \\
\cline { 2 - 3 } Treatment & \multicolumn{1}{c}{ Basal } & $45 \mathrm{~min}$ after LHRH & Basal & $45 \mathrm{~min}$ after LHRH \\
\hline Vehicle & $0.28 \pm 0.02$ & $17.8 \pm 0.8 \dagger$ & $12.6 \pm 1.3$ & $52.9 \pm 10.6 \dagger$ \\
Raloxifene $(50 \mu \mathrm{g} /$ day $)$ & $0.12 \pm 0.02^{* *}$ & $14.2 \pm 1.1 \dagger$ & $4.9 \pm 0.9^{* *}$ & $39.7 \pm 12.1 \dagger$ \\
Raloxifene $(100 \mu \mathrm{g} / \mathrm{day})$ & $0.07 \pm 0.009^{\star *}$ & $14.5 \pm 0.8 \dagger$ & $3.9 \pm 0.6^{* *}$ & $69.7 \pm 9.4 \dagger$ \\
Raloxifene $(250 \mu \mathrm{g} / \mathrm{day})$ & $0.14 \pm 0.02^{* *}$ & $13.1 \pm 1.0^{*} \dagger$ & $4.3 \pm 0.6^{* *}$ & $36.7 \pm 6.2 \dagger$ \\
Raloxifene $(500 \mu \mathrm{g} /$ day $)$ & $0.10 \pm 0.01^{* *}$ & $13.8 \pm 0.9^{*} \dagger$ & $3.9 \pm 0.4^{* *}$ & $38.5 \pm 7.5 \dagger$ \\
\hline
\end{tabular}

Data are expressed as means \pm S.E.M.; 10-12 animals per group.

${ }^{\star \star} P<0.01,{ }^{\star} P<0.05$ vs corresponding vehicle-injected group; $\dagger P<0.01$ vs basal levels; ANOVA followed by Tukey's test.

$(17,18)$. Thus, in female rats, anovulatory syndrome, hyperprolactinemia and loss of feedback actions of estrogens upon LH secretion are the major findings observed in adulthood.

In the present work, we aimed at characterizing the mechanisms of altered reproductive function following neonatal administration of raloxifene in female rats. To this end, several aspects of the function of the LHRH-LH axis were assessed in prepubertal females treated neonatally with different doses of raloxifene.

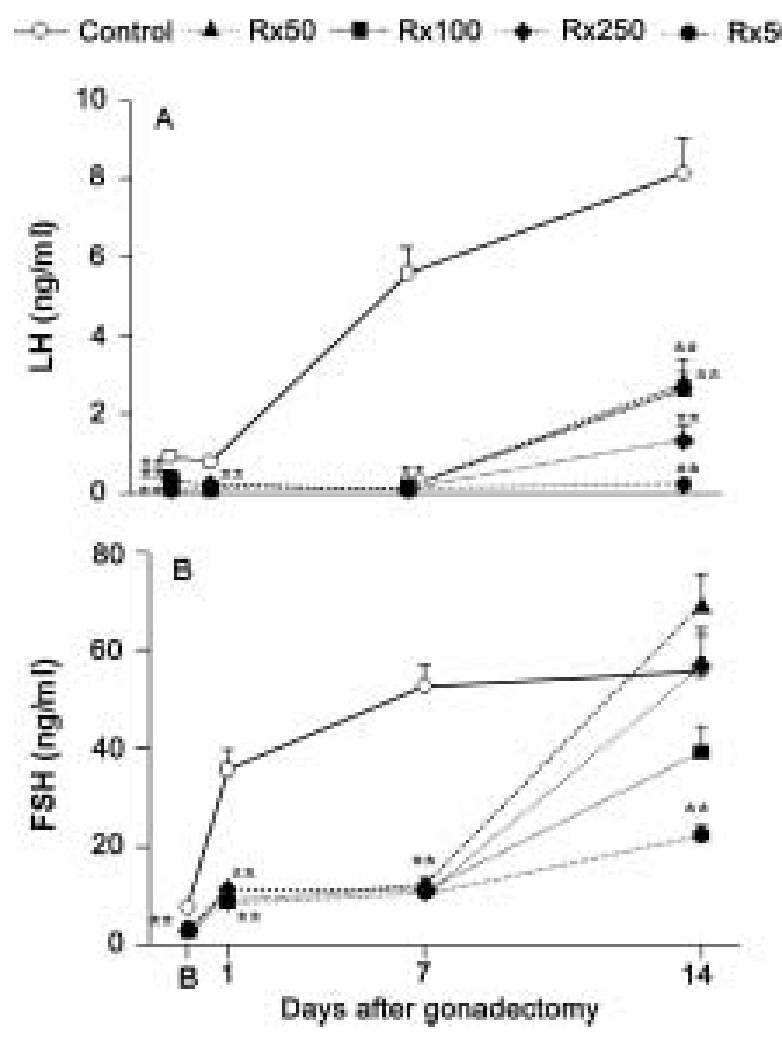

Figure 2 Serum LH (A) and FSH (B) concentration (ng/ml) in female rats treated with raloxifene $(50,100,250$ or $500 \mu \mathrm{g} /$ day) or vehicle between days 1 and 5 of age. Blood samples were obtained on day 23 (point $B$ on $x$-axis) and 1, 7 and 14 days after ovariectomy. Values are means \pm S.E.M.; $n=8-10$ animals per group. ${ }^{* \star} P<0.01$ vs vehicle-injected group; ANOVA followed by Tukey's test.
In addition, the possibility was tested that permanent changes induced by raloxifene may be due to a transient blockade of neonatal LHRH action. As major new findings, our data indicate that 23-day-old female rats neonatally injected with raloxifene showed: (1) reduced hypothalamic LHRH mRNA (Fig. 1), pituitary content of LH and FSH, and ovarian weight (Table 1); (2) decreased basal and LHRH-stimulated LH secretion in vitro (Table 2) and in vivo (Table 3); and (3) reduced LH responses after ovariectomy (Fig. 2). In addition, adult female rats treated neonatally with raloxifene presented anovulation (Table 4) and a significant reduction in serum LH levels (Table 5); these effects were not prevented by simultaneous neonatal administration of a potent LHRH-A (Tables 4 and 5).

Female rats injected neonatally with estrogen developed a permanent anovulatory syndrome in adulthood $(5,6,9,18,24)$, which is preceded by a strong reduction in pituitary content and secretion of gonadotropins immediately after neonatal injection of estrogen $(9,25)$. Similarly, the results now reported indicate that raloxifene-treated rats exhibited a decrease in pituitary content and plasma concentrations of gonadotropins after treatment that was followed in adulthood by a permanent anovulatory syndrome. The similarity between the alterations induced after neonatal administration of estradiol and raloxifene further supports the hypothesis for an estrogen-like action of raloxifene on the reproductive hypothalamus-pituitary axis. The reduced ovarian weight in raloxifene-treated animals

Table 4 Percentage of constant vaginal estrus (CVE) in 90-dayold female rats injected between days 1 and 5 of age with raloxifene, LHRH-A $(0.01 \mu \mathrm{g} / \mathrm{kg}$ per $/ 12 \mathrm{~h})$, raloxifene plus LHRH-A $(0.01 \mu \mathrm{g} / \mathrm{kg} \mathrm{per} / 12 \mathrm{~h})$ or vehicle.

\begin{tabular}{lrc}
\hline Treatment & $\boldsymbol{n}$ & $\begin{array}{c}\text { Percentage of } \\
\text { CVE rats }\end{array}$ \\
\hline Vehicle + vehicle & 10 & 0 \\
Vehicle + LHRH-A & 10 & 10 \\
Raloxifene $(250 \mu \mathrm{g} /$ day) + vehicle & 9 & 100 \\
Raloxifene $(250 \mu \mathrm{g} /$ day) + LHRH-A & 10 & 100 \\
Raloxifene $(500 \mu \mathrm{g} /$ day) + vehicle & 10 & 100 \\
Raloxifene $(500 \mu \mathrm{g} /$ day) + LHRH-A & 10 & 100 \\
\hline
\end{tabular}


Table 5 Serum LH and FSH concentrations in 90 day-old female rats injected between days 1 and 5 of age with raloxifene, LHRHA $(0.01 \mu \mathrm{g} / \mathrm{kg}$ per $12 \mathrm{~h})$, raloxifene plus LHRH-A $(0.01 \mu \mathrm{g} / \mathrm{kg}$ per $12 \mathrm{~h})$ or vehicle.

\begin{tabular}{llc}
\hline Treatment & LH $(\mathrm{ng} / \mathrm{ml})$ & FSH $(\mathrm{ng} / \mathrm{ml})$ \\
\hline Vehicle + vehicle & $2.8 \pm 0.5$ & $1.1 \pm 0.2$ \\
Vehicle + LHRH-A & $4.3 \pm 1.0$ & $1.4 \pm 0.4$ \\
Raloxifene $(250 \mu \mathrm{g} /$ day $)+$ vehicle & $1.0 \pm 0.2^{\star \star}$ & $1.8 \pm 0.3$ \\
Raloxifene $(250 \mu \mathrm{g} /$ day) + LHRH-A & $1.1 \pm 0.2^{\star \star}$ & $1.7 \pm 0.3$ \\
Raloxifene $(500 \mu \mathrm{g} /$ day) + vehicle & $0.4 \pm 0.07^{\star \star}$ & $1.4 \pm 0.07$ \\
Raloxifene $(500 \mu \mathrm{g} /$ day $)+$ LHRH-A & $0.6 \pm 0.2^{\star \star}$ & $0.9 \pm 0.05$ \\
\hline
\end{tabular}

Data are expressed as means \pm S.E.M.; 9-10 animals per group.

** $P<0.01$ vs vehicle + vehicle-injected group; ANOVA followed by Tukey's test.

reported here agrees with previous data (17), and is probably related to the decrease in serum gonadotropin concentrations induced by neonatal raloxifene, although a direct action of raloxifene upon the ovary cannot be excluded on the basis of the present experiments.

Since raloxifene has an elimination half-life of $11-$ $27 \mathrm{~h} \mathrm{(26),} \mathrm{the} \mathrm{effects} \mathrm{now} \mathrm{reported} \mathrm{in} \mathrm{prepubertal} \mathrm{and}$ adult rats confirm that raloxifene, administered during the neonatal period of sex differentiation, permanently changes the functional organization of the mechanisms controlling gonadotropin secretion. In principle, this action can be carried out directly at the hypothalamus, probably by acting upon the LHRH neurons that do express estrogen receptors (27), at the pituitary, or at both levels. In this sense, our data strongly suggest that the reproductive defects induced by neonatal administration of raloxifene are linked to permanent changes in the functioning of the LHRH-LH unit, but not to a transient decrease in LHRH input on neonatal pituitary due to raloxifene administration, as co-treatment with a potent LHRH-A failed to counteract the reproductive effects of raloxifene alone.

In prepubertal females treated neonatally with raloxifene, hypothalamic GnRH mRNA levels were significantly reduced (Fig. 1), thus suggesting that raloxifene is able to induce a decrease in the expression of this hypothalamic neuropeptide. This phenomenon, however, may not account for all the changes observed in prepubertal females following neonatal raloxifene treatment, as, in addition, significant decreases in LHRH-stimulated LH and FSH serum levels and in the response to ovariectomy were observed. Considering that LH responses to LHRH were reduced both in vivo and in vitro, it is temping to postulate that a pituitary decrease in responsiveness to LHRH is primarily involved in the decrease of LH secretion observed in female rats treated neonatally with raloxifene, both under basal and postovariectomy conditions. Several mechanisms may underlie such a decrease in pituitary responsiveness to exogenous LHRH administration (Tables 2 and 3). Among them, a reduction in the number and/or affinity of LHRH pituitary receptors can be involved. It is noteworthy that an appropriate release of endogenous LHRH is necessary to maintain the number and functionality of pituitary LHRH receptors (28-32). Thus, decreased hypothalamic LHRH expression and/or release might contribute to the observed reduction in pituitary LH responsiveness to LHRH in raloxifene-treated female rats.

Selective profiles of release of both gonadotropins are related to the frequency and amplitude of LHRH pulses. Pituitary stimulation with low-frequency LHRH pulses selectively stimulates FSH secretion $(33-35)$ whereas high frequencies preferentially stimulate LH secretion (36). Since neonatal raloxifene treatment affected $\mathrm{LH}$ secretion more severely than FSH secretion (17 and present results), it is tempting to postulate that, in addition to a net reduction in LHRH expression, raloxifene may also alter the pattern of pulsatile release of hypothalamic LHRH. Nevertheless, further experimental work is needed to substantiate this hypothesis.

In conclusion, our present experiments demonstrate that neonatal exposure to raloxifene permanently changed several aspects of the function of the hypothalamic-pituitary-ovarian axis; a phenotype that was not counteracted by simultaneous administration of a potent LHRH agonist. Overall, female rats treated neonatally with raloxifene showed persistently reduced LH secretion, under basal and LHRH-stimulated conditions and after ovariectomy, that is probably related to decreased LHRH expression, reduced pituitary LH content, and/or decreased pituitary responsiveness to hypothalamic LHRH.

\section{Funding}

This work was supported by grants from DGESIC (Ministerio de Ciencia y Tecnología, Spain) and EU research contract EDEN QLK4-CT-2002-00603.

\section{References}

1 Whalen RE \& Edwards DA. Effects of the anti-androgen cyproterone acetate on mating behaviour and seminal vesicle tissue in male rats. Endocrinology 196984 155-161.

2 Johnson LM \& Gay VL. Influence of perinatal androgenization on the castration response of adult rats. Biology of Reproduction 1983 29 819-823.

3 Pozzo-Miller LD \& Aoki A. Stereological analysis of the hypothalamic ventromedial nucleus. II Hormone-induced changes in the synaptogenic pattern. Brain Research. Developmental Brain Research 199161 189-196.

4 Wall A \& Meyerson BJ. Neonatal castration and adult responsiveness to testosterone in male rats: an interstrain comparison. Physiology and Behaviour 199762 1371-1378.

5 Barraclough CA. Production of anovulatory sterile rats by single injection of testosterone propionate. Endocrinology $1961 \mathbf{6 8}$ $62-67$.

6 Gorski RA. Modification of ovulatory mechanisms by postnatal administration of estrogen in the rat. American Journal of Physiology $1963205842-844$

7 Gorski RA. Sexual differentiation of the brain: comparative aspects. In Control of the Onset of Puberty, pp 231-250. Eds ML 
Grumbach, PC Sizonenko \& ML Aubert. Baltimore: William \& Wilkins, 1990.

8 Aguilar E, Fernández-Galaz C, Tejero A \& Vaticón MD. PRL response to LHRH in neonatally estrogen treated female rats. Acta Endocrinologica 1979225197.

9 Pinilla L, Trimiño E, Garnelo P, Bellido C, Aguilar R, Gaytan F et al. Changes in pituitary secretion during the early postnatal period and anovulatory syndrome induced by neonatal oestrogen or androgen in rats. Journal of Reproduction and Fertility 199397 $13-20$.

10 Wakeling AE, Valcaccia B, Newboult E \& Green LR. Non-steroidal antioestrogens-receptor binding and biological response in rat uterus, rat mammary carcinoma and human breast cancer cells. Journal of Steroid Biochemistry 198420 111-120.

11 Glasebrook AL, Philips DL \& Sluka JP. Multiple binding sites for the antiestrogen raloxifene (156758). Journal of Bone and Mineral Research 19938 (Suppl 1) A607.

12 Yang NN, Venugopalan M, Hardikar S \& Glasebrook A. Identification of an estrogen response element activated by metabolites of $17 \beta$-estradiol and raloxifene. Science $1996 \quad \mathbf{2 7 3}$ 1222-1225.

13 Delmas PD, Bfarnason NH, Mitlak BH, Ravoux AC, Shah AS, Huster WJ et al. Effects of raloxifene on bone mineral density, serum cholesterol concentration and uterine endometrium in postmenopausal woman. New England Journal of Medicine 1997 337 1641-1647.

14 Buelke-Sam J, Cohen JR, Wierda D, Griffey KI, Fisher LF \& Francis PC. The selective estrogen receptor modulator raloxifene: a segment II/III delivery study in rats. Reproductive Toxicology $199812271-288$.

15 Ashby J, Odum J \& Foster JR. Activity of raloxifene in inmature and ovariectomized rat uterotrophic assays. Regulatory Toxicology and Pharmacology $199725226-231$.

16 Palkowitz AD, Glasebrook AL, Thrasher KJ, Hanser KL, Short LL, Phillis DL et al. Discovery and synthesis of [6-hydroxy-3[4-[2-(1-piperidinyl) etoxy] phenoxy] 2-(4-hidroxyphenyl)] benzo [b] thiophene: a novel, highly potent, selective estrogen receptor modulator. Journal of Medical Chemistry $1997 \mathbf{4 0}$ 1407-1416.

17 Pinilla L, Gonzalez LC, Gaytan F, Tena-Sempere M \& Aguilar E. Oestrogenic effects of neonatal administration of raloxifene on hypothalamic-pituitary-gonadal axis in male and female rats. Reproduction $2001121915-924$.

18 Pinilla L, Barreiro ML, Gonzalez LC, Tena-Sempere M \& Aguilar E. Comparative effects of testosterone propionate, oestradiol benzoate, ICI 182,780 , tamoxifen and raloxifene on hypothalamic differentiation in the female rat. Journal of Endocrinology 2002 $172441-448$.

19 Pinilla L, Gonzalez LC, Tena-Sempere M \& Aguilar E. Evidence for an estrogen-like action of raloxifene upon the hypothalamic-pituitary unit: raloxifene inhibits luteinizing hormone secretion and stimulates prolactin secretion in ovariectomized female rats. Neuroscience Letters $2001311149-152$.

20 Haggi E \& Aoki A. Prolactin content in rat pituitary gland. RIA of prolactin after different extraction procedures. Acta Endocrinologica $198197338-342$.

21 Chomczynski P \& Sacchi N. Single-step method of RNA isolation by acid guanidinium thiocyanate-phenol-chloroform extraction. Analytical Biochemistry 1987162 156-159.

22 Botté M-C, Chamagne AM, Carré MC, Counis R \& Kottler ML. Fetal expression of GnRH and GnRH receptor genes in rat testis and ovary. Journal of Endocrinology 1998159 179-189.
23 Tena-Sempere M, Barreiro ML, Gonzalez LC, Gaytan F, Zhang FP, Caminos JE et al. Novel expression and functional role of ghrelin in rat testis. Endocrinology $2002143717-725$.

24 Mallampatti RS \& Johnson DC. Serum and pituitary prolactin, LH and FSH in androgenized female and normal rats treated with various doses of estradiol benzoate. Neuroendocrinology 197311 46-56.

25 Pinilla L, Lopez F, Gonzalez D, Fernandez-Galaz C, Sanchez-Criado JE \& Aguilar E. Luteinizing-hormone-mediated precocious puberty induced in female rats by a prepubertal pituitary graft. Neuroendocrinology $1989 \mathbf{5 0} 495-499$.

26 Balfour JA \& Goa KL. Raloxifene. Adis New Drug Profile 199812 336-341.

27 Herbison AE \& Pape JR. New evidence for estrogen receptors in gonadotrophin-releasing hormone neurons. Frontiers in Neuroendocrinology 200122 292-308.

28 Frager MS, Pieper DR, Tonetta SA, Duncan JA \& Marshall JC. Pituitary gonadotropin-releasing hormone receptors: effects of castration, steroid replacement, and the role of gonadotropinreleasing hormone in modulating receptors in the rat. Journal of Clinical Investigation 198167 615-623.

29 Clayton RN \& Catt KJ. Regulation of pituitary gonadotropinreleasing hormone receptors by gonadal hormones. Endocrinology $1981108887-895$.

30 Marian J, Cooper RL \& Conn PM. Regulation of the rat pituitary gonadotrophin-releasing hormone receptor. Molecular Pharmacology $198119399-405$.

31 Yasin M, Dalkin AC, Haislender DJ, Kerrigan JR \& Marshall JC. Gonadotropin-releasing hormone $(\mathrm{GnRH})$ pulse pattern regulates GnRH receptor gene expression: augmentation by estradiol. Endocrinology $19951361559-1564$.

32 Kaiser UB, Jakubowiak A, Steinberger A \& Chin WW. Differential effects of gonadotropin-releasing hormone (GnRH) pulse frequency on gonadotropin subunit and $\mathrm{GnRH}$ receptor messenger ribonucleic acid levels in vitro. Endocrinology $1997 \mathbf{1 3 8}$ 1224-1231.

33 Wildt L, Hausler A, Marshall G, Hutchinson J, Plant T, Belchetz P et al. Frequency and amplitude of gonadotropin-releasing hormone stimulation and gonadotropin secretion in the rhesus monkey. Endocrinology 1981109 376-385.

34 Clarke IJ, Cummins JT, Findlay JK, Burman KJ \& Doughton DW. Effects on plasma luteinizing hormone and follicle-stimulating hormone of varying the frequency and amplitude of gonadotropin-releasing hormone pulses in ovariectomized ewes with hypothalamic-pituitary disconnection. Neuroendocrinology 1984 $39214-221$.

35 Dalkin AC, Haisenleder DJ, Ortolano GA, Ellis TR \& Marshall JC. The frequency of gonadotropin-releasing hormone stimulation differentially regulates gonadotropin subunit messenger ribonucleic acid expression. Endocrinology 1989125 917-924.

36 Papavasiliou SS, Zmeili S, Khoury S, Landefeld TD, Chin WW \& Marshall JC. Gonadotropin-releasing hormone differentially regulates expression of the alpha and luteinizing hormone beta subunit genes in male rats. PNAS 198683 4026-4029.

Received 9 July 2003

Accepted 21 November 2003 